\title{
Current trends in the development of the Russian agrarian economy in ensuring food security
}

\author{
Olga V. Kirillova1,," Alfiya F. Sadreeva², Svetlana V. Markova², and Farida A. Mukhametshina ${ }^{2}$ \\ ${ }^{1}$ Kazan State Agrarian University, Kazan, 420015, Russia \\ ${ }^{2}$ Kazan National Research Technical University named after A. N. Tupolev - KAI (KNITU-KAI), Kazan, 420015, Russia
}

\begin{abstract}
The situation in the Russian Federation in the spring of 2020 is quite serious and directly related to ensuring food security. Achieving the country's food security always depends on the ability of the state to overcome threats and risks of various kinds. There is the situation that requires a rapid study of information, accumulation of available resources, the creation of the necessary reserves and the determination of current directions for the development of the agrarian economy in such emergency conditions. But in these conditions, Russia has faced many problems that need to be addressed in the short term. The need for state support for agriculture in this situation is clear and more necessary than ever. At the same time, we must consider its features determining the directions, forms and methods of state support. The article determines that for the development of the agrarian economy and ensuring food security of the country require sustainable development of agricultural production, raw materials and food, the implementation of policies to support the neediest segments of the population and poverty alleviation, the development of interregional integration, the development of transport and logistics infrastructure to support the regions, support for farms, the formation of the state reserve of agricultural products, raw materials and products nutrition, the creation of a network of distribution centres under the mechanism of domestic food assistance to the population, etc.
\end{abstract}

\section{Introduction}

Currently, in the spring of 2020, the Russian economy is going through quite difficult times. This is primarily due to the following problems:

1. Sharp decline in prices for oil and petroleum products;

2.Low ruble exchange rate relating to the dollar and other world currencies;

3. Closing borders between countries and almost complete cessation of international trade;

4. Quarantine and self-isolation of the population;

5. Growth of social conflicts and the emergence of panic among the country's population;

6. Reduction of population incomes and cheaper savings and deposits;

7.Problems of non-payment of wages, especially in small businesses;

8. Dismissal of employees or sending them on forced administrative leave;

9. Bankruptcy of economic entities;

10. Closing enterprises for an indefinite period, etc.

All these problems have aggravated the situation in the country's food market. Enterprises and the population faced with the urgent issue of ensuring food security for both an individual family and the country as a whole.

Shortly before the crisis, the Decree of the President of the Russian Federation dated January 21, 2020 No. 20 approved the Doctrine of Food Security of the Russian Federation, which defines the goals, objectives and main directions for ensuring this security. Such safety means a guarantee of the accessibility for every Russian citizen of food products of the required quality to ensure an active and healthy lifestyle. This doctrine is the basis for the development of legal acts in the field of agriculture and fisheries [1].

The main risks and threats to food insecurity are the following:

1. Change in climatic conditions that will not allow the growing and producing products;

2. The crisis in the banking sector and the deterioration of the situation in international payments;

3.High inflation and the presence of inflationary expectations among the population;

4.Increased political instability and deteriorating relations among countries, etc.

It becomes obvious that the current situation in Russia just determines the aggravation of the issue of ensuring food security because the problems that arose and possible risks to the maximum extent in the spring of 2020 paralysed the country's economic activity. In addition, Russia already has its characteristics of the agrarian economy based on the definition of the directions of development and the provision of food to the population.

* Corresponding author: Lesik333@yandex.ru 
For the Russian Federation, the relevant features of agricultural development include a shortage of highly qualified personnel; understaffing of machinery and equipment; low labour productivity; problems of rational use of available resources, etc. [2].

The food safety doctrine of the Russian Federation determines that the threshold values for self-sufficiency should have the following indicators:

1. Grain $-95 \%$;

2. Sugar $-90 \%$;

3. Vegetable oil $-90 \%$;

4. Meat and meat products $-85 \%$;

5. Milk and dairy products $-90 \%$;

6. Fish and fish products $-85 \%$;

7. Potatoes $-95 \%$;

8. Vegetables and melons $-90 \%$;

9. Fruits and berries $-60 \%$;

10. Seeds of agricultural crops of domestic origin $75 \%$;

11. Food salt $-85 \%$.

It is clear that these thresholds will not be easy to reach under the current circumstances because agricultural production is based on imported components as feed, food additives, etc. Moreover, the security of Russian regions is completely different in terms of indicators since food production and availability in one region differ markedly from another [3, 4].

Thus, there is the situation that requires a rapid study of information, accumulation of available resources, the creation of the necessary reserves and the determination of current directions for the development of the agrarian economy in such emergency conditions. But in these conditions, Russia has faced many problems that need to be addressed in the short term. At the same time, Russia has many advantages, as it is an opportunity to restore or increase the competitiveness of the main sectors of the economy.

\section{Materials and Methods}

According to analytical data, the level of food security in Russia as a whole is $89 \%$. For example, the actual value for grain is $134.8 \%$; for vegetable oil, it is $132.4 \%$; for sugar, it is $87.8 \%$. That is, these indicators today reflect a $100 \%$ or more level of security. But there are industries whose products not provide the necessary level of safety and are also imported from other countries. For example, milk and dairy products make up $80 \%$ of the supply, meat and meat products $-76 \%$. On average, it is about 10 percentage points below the required level of security in the country [5].

As for vegetables, their supply is approximately $30 \%$, and a certain level of safety is $90 \%$. Here, such a feature of agriculture as a long-term period for the payback and achievement of the required production volumes has its imprint. The problem remains both the number of new vegetable stores and the modernization of old ones. In these conditions, the role of vegetable stores increases to the highest level, since the regions of Russia need to create reserves for providing the population with food without delay.
Reserves should be created not only for vegetables but also for other foodstuffs because the population additionally creates artificial demand by buying more products than necessary. In most countries of the world, there is a violation of food supply chains that can lead to disastrous consequences [6].

The Russian government is already deciding to limit exports of certain types of key goods. The measures taken will affect the following products: wheat, corn, barley and rye. The Ministry of Economic Development has determined that the proposed quota will be 7 million tons.

Enormous delays in providing the population with food can become one of the acute problems of food security. It can result in socio-economic upheavals, so the state needs to work out logistics product chains in advance to prevent such a situation. The probability of a lack of products or the possibility of purchasing them can result in mass riots and political unrest among the population $[7,8]$.

The forecast of the Federal Service for Hydrometeorology and Environmental Monitoring plays a special role and, unfortunately, is not very encouraging. Experts predict a serious drought on the Russian Plain because less than $10 \%$ of the average annual rainfall fell there during the winter. And the Russian agro-industrial complex is very dependent on climatic conditions which will significantly affect the harvest in the future. Moreover, the crop industry, on which the fodder base for livestock breeding and the production of cereals depends entirely, will be in the worst position $[9,10]$.

The introduction of a self-isolation regime is of particular importance since many regions of the Russian Federation imposed a ban on travel outside the city. Naturally, all gardeners sounded the alarm, since personal farming is a good help for many families and provides food for several autumn and winter months. The government understands how necessary and serious it is for the population and takes measures through the introduction of access control and additional documentation.

For example, in several districts of the Republic of Tatarstan, there is a quarantine at agricultural enterprises. So, it is recommended to organize shift work among teams to exclude contacts between them. This is a measure to ensure the functioning of the entire enterprise.

The situation of Russian farmers is further aggravated by the fact that at the start of the sowing season they need money to purchase agricultural machinery, spare parts, fuels, lubricants, and seeds. The banks that provided the necessary loans to agricultural producers resolved many issues, but at present, most financial and credit institutions have reduced the volume of work, that creates additional difficulties for the agricultural sector of the economy. An additional fly in the ointment is the fact that Russia has introduced measures to postpone the payment of taxes for small businesses.

It would seem that the measures taken are correct, but the Federal Tax Service indicates that small businesses can rely on government subsidies only if they 
do not have previous debt. As a rule, most agricultural producers have debts to pay, so they automatically lose such support.

At the same time, domestic farmers and milk producers are concerned that Russia will introduce mandatory digital marking of finished dairy products from June 1, 2020. This procedure has already required the expenditure of funds for the purchase of appropriate equipment and databases. But, representatives of the milk processing industry believe that it is impossible to complete this process in the current conditions.

Moreover, small farms will not be able to absorb such costs and will be forced to give way to larger producers. And the enterprises will have to cover considerable costs at the expense of the final buyers of milk and dairy products. In other words, price growth becomes inevitable $[11,12]$.

The key now for Russia is the timely start of the sowing campaign without disruption and postponements, otherwise, crops, especially cereals, could be lost in the autumn. This will also entail a reduction in the country's export opportunities, as Russia is one of the top exporters of grain [13].

The threat to the country's food security is also the lack of revenue from domestic agricultural producers. For the country as a whole, a reduction in grain exports will result in the possible loss of previously won niches in the international market. This applies to the Middle East and the Persian Gulf countries.

If in the current conditions agricultural production is reduced, then against the background of a sharp decline in oil and oil products prices and the devaluation of the rouble, the country will find itself in very harsh conditions.

First, it is due to the fact that the bulk of the population spends up to $50 \%$ of their budget on food products at present. Soon, the inevitable increase in prices for goods and services may increase this share to $70-80 \%$. But it also happens in conditions of delay or partial non-payment of wages to almost all economic entities. Therefore, the state needs to develop a set of measures to prevent the situation and mitigate possible negative consequences.

As it was determined, in some constituent entities of the Russian Federation there are cases of noncompliance with the Food Security Doctrine of the Russian Federation. For example, the Far East and some regions of Siberia are heavily dependent on imports from China. And under the prevailing conditions, food security sharply decreased in these regions, i.e. this was affected by the consequences of the general self-isolation regime of countries and the impossibility of a quick response of the Central Federal District to problems that arose in the Far East. Moreover, the cost of products immediately increased in price.

Until today, China supplied significant volumes of vegetables, up to $22.4 \%, 16.5 \%$ of processed products of fruits and vegetables, $14.9 \%$ of fish and crustaceans, $13.3 \%$ of finished meat and fish products. But for some markets, China's share in Russian imports is much higher. For example, the share in the import of fish fillet is $29.1 \%$, rabbit and pigeon meat is $37.1 \%$, peanut butter is $39.8 \%$, cabbage is $43.7 \%$, cooked or canned tomatoes is $48.4 \%$, garlic and onions is $48.7 \%$, ginger, saffron, thyme is $49.5 \%$, dried vegetables is $57.1 \%$, shellfish is $58.6 \%$, cooked or canned mushrooms and truffles is $92.4 \%[14,15]$.

Thus, in the spring of 2020, the main agricultural risks for countries include restrictions on international trade in agricultural products introduced by individual governments, difficulties with logistics, leading to interruption of its supply chains to final consumers in the domestic and foreign markets, as well as restrictions on the mobility of agricultural labour inside countries relating to quarantine measures taken.

\section{Results}

Therefore, the Russian Federation needs to take the necessary measures that will allow the state to make the agricultural sectors of Russia invulnerable, which will immediately affect the improvement of the quality and income of the country's population. And, most importantly, to ensure the country's food security at the required level [16].

To develop the agricultural economy and ensure the food security of the country, it is necessary to implement the following areas:

1.Sustainable development of agricultural production, raw materials and food sufficient to ensure the country's food security based on the principles of science-based planning;

2. Minimization of negative consequences due to the constant readiness of the system to provide the population with food products and form strategic reserves;

3. Implementation of policies to support the neediest segments of the population and reduce poverty;

4. Development of interregional integration in the field of food security

5. Technical re-equipment of agricultural production in conditions of the active participation of state support;

6. Development of transport and logistics infrastructure to support regions in emergencies;

7.Support to farms in obtaining credit funds and subsidization of production costs;

8. Formation of the state reserve of agricultural products, raw materials and food;

9. Increase in crop yields, preserving, restoring and improving the fertility of agricultural land

10. Creation of a network of wholesale distribution centres for the purchase of products from agricultural producers, their processing, storage and marketing through the retail and procurement system for state and municipal needs, including through the mechanism of domestic food assistance to the population;

11. Increase in the number of retail facilities selling food products, including agricultural products, raw materials and food.

The implementation of the developed Doctrine of Food Security of the Russian Federation, which will ensure, with effective management, the necessary level and quality of providing the population with food [17] is 
of particular importance for ensuring food security of the country.

Thus, the situation in the Russian Federation in the spring of 2020 is quite serious and directly related to ensuring food security. Achieving the country's food security always depends on the ability of the state to overcome threats and risks of various kinds.

As is already known, the natural resource potential of Russia is a strategic resource, which, if used correctly and efficiently, will provide the population with food, but also have an indispensable export advantage.

Since domestic producers began to increase food prices, the purchasing power of the population began to decline sharply with investment conditions. The depreciation of the national currency and falling prices for oil and petroleum products exacerbates the situation. This situation critically affects the food security of the country, which directly depends on the efficient use of available resources and economic development in the agricultural sector.

The need for state support for agriculture in this situation is clear and more necessary than ever. At the same time, we must consider its features determining the directions, forms and methods of state support.

It is necessary to ensure control over the implementation of measures and directions in the agrarian sector to ensure food security for the state. Meanwhile, insufficient and untimely financing of programs and projects of measures to ensure food security and lack of control can result in a complete lack of results and controversial situations.

\section{Conclusion}

Russia has the necessary assets to achieve its objectives defined by the Food Security Doctrine of the Russian Federation. Moreover, the most important advantages are the vast area of agricultural land, the available factors of production, labour resources, etc. The state must organize their effective use and application to achieve the objectives and provide the necessary support.

\section{References}

1. E.F. Amirova, L.I. Petrova, E.V. Ziuzya et al., Import substitution as an economic incentive mechanism for Russian commodity producers, Int. J. of Civil Engineer. and Technol., 10(2), 926-931 (2019)

2. E.F. Amirova, O.Yu. Voronkova, N.R. Zakirova et al., Internet of things as a tool for the development of Russia's digital economy, Int. J. of Mechan. Engineer. and Technol., 10(2), 1011-1019 (2019)

3. E.Yu. Ermakova, Yu.F. Korotkov et al., Cleaning contaminated water by gravity flotation, Chem. and Petrol. Engineer., 46(1-2), 40-44 (May 2010)
4. P.B. Akmarov, M.Kh. Gazetdinov, O.P. Knyazeva, The state and main directions of development of the digital economy in agriculture of Russia, Bull. of Kazan State Agrar. Univer., 1(52), 106-111 (2019)

5. M.F. Amirov, The effect of trace elements and mineral fertilizers on the yield and quality of grain of spring wheat, Bull. of Kazan GAU, 4(47), 5-8 (2017) (Kazan)

6. S.V. Bodrikova, G.S. Klychova, A.N. Bodrikova, The development of import substitution and employment in the modern economy of Russia, Bull. of Kazan State Agrar. Univer., 13(4(51)), 140-145 (2018)

7. A.N. Valeeva, O.S. Semicheva, D.N. Valeeva, Optimization of traffic flows in the supply chain management of a food company, Bull. of Kazan State Agrar. Univer., 12(2(44)), 126-132 (2017)

8. M.Kh. Gazetdinov, O.S. Semicheva, Sh.M. Gazetdinov, Social and labour aspects of the economic mechanism of rural development, Technique and equipment for the village, 10, 36-40 (2017)

9. F.F. Gatina, A.R. Artamonicheva, Investment activity of the Republic of Tatarstan in the agricultural sector of the economy, Econ. of agricult. and proc. Enterprises, 7, 50-52 (2008)

10. A.R. Zakirova, Actual issues of the organization of management accounting in agricultural organizations following international financial reporting standards, Bull. of Kazan State Agrar. Univer., 5(4(18)), 32-36 (2010)

11. O.V. Kirillova, Economics of the agro-industrial complex of Russia at the present stage in conditions of instability of the external environment, in the collection: Fundamental and applied research: from theory to practice, Mater. of the II Int. sci.-pract. Conf., dedicated to the Day of Russian Science pp. 100-103 (2018)

12. O.V. Kirillova, Priority areas for ensuring food security in Russia, considering the analysis of the strengths and weaknesses of the country's economy, Bull. of Kazan State Agrar. Univer,. 14(2(53)), 150-153 (2019)

13. A.S. Klychova, S.F. Girfanov, G.D. Krupina, I.N. Safiullin, Increasing competitiveness in the conditions of corporate governance of enterprises of the agro-industrial complex of the Republic of Tatarstan, Bull. of Kazan State Agrar. Univer., 12(4(46)), 110-115 (2017)

14. D.I. Fayzrakhmanov, L.R. Shagivaliev, F.T. Nezhmetdinova, Improving the efficiency of staffing in the agricultural sector in the Republic of Tatarstan based on a cluster approach, Bull. of the Kazan State Agrar. Univer., 2(1), 104 (2014)

15. M.F. Amirov, I.R. Valeev, A.R. Valiev et al., Rules for the development of technological maps in crop production, In: The system of agriculture of the Republic of Tatarstan, In 3 parts, pp. 281-283 (Kazan, 2014) 
16. A.K. Subaeva, L.M. Mavlieva, N.R. Alexandrova, M.M. Nizamutdinov, Technical modernization of the land reclamation system as a reserve for improving agricultural efficiency, Bull. of Kazan State Agrar. Univers., 12(3(45)), 124-127 (2017)
17. D.I. Fayzrakhmanov, Sh.M. Gazetdinov, Problems of development of small and medium enterprises in the agricultural sector of the economy, Bull. of Kazan State Agrar. Univer., 9(1(31)), 38-42 (2014) 